\title{
Valutaire winden rond de jaarrekening
}

Citation for published version (APA):

Brink, H. L. (1995). Valutaire winden rond de jaarrekening. Maastricht University. https://doi.org/10.26481/spe.19950609hb

Document status and date:

Published: 09/06/1995

DOI:

10.26481/spe.19950609hb

Document Version:

Publisher's PDF, also known as Version of record

\section{Please check the document version of this publication:}

- A submitted manuscript is the version of the article upon submission and before peer-review. There can be important differences between the submitted version and the official published version of record.

People interested in the research are advised to contact the author for the final version of the publication, or visit the DOI to the publisher's website.

- The final author version and the galley proof are versions of the publication after peer review.

- The final published version features the final layout of the paper including the volume, issue and page numbers.

Link to publication

\footnotetext{
General rights rights.

- You may freely distribute the URL identifying the publication in the public portal. please follow below link for the End User Agreement:

www.umlib.nl/taverne-license

Take down policy

If you believe that this document breaches copyright please contact us at:

repository@maastrichtuniversity.nl

providing details and we will investigate your claim.
}

Copyright and moral rights for the publications made accessible in the public portal are retained by the authors and/or other copyright owners and it is a condition of accessing publications that users recognise and abide by the legal requirements associated with these

- Users may download and print one copy of any publication from the public portal for the purpose of private study or research.

- You may not further distribute the material or use it for any profit-making activity or commercial gain

If the publication is distributed under the terms of Article $25 \mathrm{fa}$ of the Dutch Copyright Act, indicated by the "Taverne" license above, 
lalumare winden rond de aarrekening

Rede

uitgesproken ter gelegenheid van het afscheid als hoogleraar International Accounting aan de Rijksuniversiteit Limburg op 9 juni 1995

door

Prof. H.L. Brink RA 


$$
P=13869947 x
$$

Univerell ambolitiotheok

Bifyeunivoriten Lintoung 
Mijnheer de Rector Magnificus

Leden van de universitaire gemeenschap

Geachte toehoorders

Er is een tijd van komen en er is een tijd van gaan. Bij het komen is het gebruikelijk een oratie te houden, bij het gaan spreekt men een laatste woord, een afscheidsrede.

Ik heb geprobeerd uit te zoeken wat het onderwerp en de inhoud van een dergelijke afscheidsrede in de praktijk is. Het is mij gebleken dat daarvoor in de meeste gevallen een actueel onderwerp wordt gekozen, een onderwerp bovendien waarmee degene die afscheid neemt zich de laatste tijd min of meer intensief heeft bezig gehouden. Je zou ook kunnen zeggen: het is een aan de omstandigheden aangepast college. Vooral mijn postdoctorale studenten zullen in deze afscheidsrede veel herkenningspunten ontdekken.

Dit als uitgangspunt nemende had ik een zeer grote keuze. Ik zal $\mathrm{U}$ een paar mogelijke onderwerpen noemen.

1. De nagenoeg complete ondergang van de toepassing van actuele waarde in de jaarrekening van Nederlandse ondernemingen was een goed onderwerp geweest. Was dit niet jarenlang het vlaggeschip van de Nederlandse verslaggeving en is dit schip nu opgelegd voor later gebruik of is het definitief gesloopt? '

2. Ook de harmonisatie van de wet- en regelgeving in internationaal verband was een goed onderwerp geweest. Wij zien daal thans interessante ontwikkelingen zowel in Nederland als daar. buiten in die zin dat "men" zich hevig verzet tegen elk aanhaler van de teugels van de wet- en regelgeving. Ondernemingen dis als toonaangevend, bekend staan, ik noem U Philips in ons 


\section{lalwaire winden rond de jaarrekening}

eigen land, Daimler Benz en PeugeotCitroën in het buitenland, die zich op geheel vrijwillige basis onderwerpen aan de strengste en meest uitgebreide regelgeving ter wereld namelijk die in de Verenigde Staten? ${ }^{2}$

3. Een minder prettig, maar wel een zeer actueel onderwerp was geweest de zorg om de kwaliteit van de Nederlandse jaarverslaggeving en in één adem daarmee de kwaliteit van de opstellers (de controllers) en die van de controleurs (de accountants) van deze verslaggeving. ${ }^{3}$

Eén van de mij moverende redenen om deze onderwerpen niet te kiezen is gelegen in het feit dat ik mij op een andere plaats over deze onderwerpen nog zal uitlaten. In de gedrukte versie van deze rede is dit in voetnoten uitgewerkt. Een andere reden is dat het hier toch wel om onderwerpen gaat die meer dan normale specialistische kennis op het gebied van de accounting vereisen, kennis die ik niet bij elke toehoorder als aanwezig mag veronderstellen.

Welk onderwerp heb ik dan wél gekozen? Ik citeer enkele losse willekeurige stukjes uit recente kranteberichten. Vooral onder druk van valutaire tegenwind heeft de Amsterdamse Effectenbeurs sinds het begin van dit jaar nauwelijks enige performance vertoond. (Uit een advertentie van de RABObank in NRC Handelsblad van 10 mei 1995) Grote beleggers worden natwelijks zemuwachtig van de lagere dollar en het Britse pond, die de totale Unileverwinst met zeven procent hebben gedrukt. (Uit 'Vertrouwen in Unilever krijgt tik' in NRC Handelsblad van 19 mei 1995. De algemeen directeur van Stork pompen heeft intern een andere functie gekregen, nadat hij onder meer verlie- 
z'n he'fi geleden op met gemelde valutatransacties met Amerihacumse dollars (NRC Handelsblad van 29 maart 1995). En de laatste van de vele die ik nog zou hebben: Het (activiteiten op het terrein van de derivaten) is voor ons een min of meer nieuwe lak van sport. The alandacht voor dit soort produkten is sterk gegroerd. We gaur dacarin mee omdat de klanten het vragen. t.ll omdat er wat te verdienen valt natmurlijk. (De Limburger van 26 april 1995 Ook RABO breidt fors uit in de derivatenmarkt) Samengevat: hier ligt een dankbaar en actueel onderwerp voor een afscheidsrede.

De valutamarkten zijn sterk in beweging en de dollar, de lire en de peseta, on een paar voorbeelden te noemen, bereiken steeds weer nieuwe dieptepunten. Ik veronderstel dat ieder die dit jaar in het buitenland op vakantie gaat deze ontwikkelingen op de voet volgt. Ander nieuws is de ondergang van de Britse bank van standing Barings, een ondergang die, als alle verhalen in de krant daarover waar zijn, werd bewerkstelligd door een enkele employe in Singapore. Zijn ondergang werd de handel in derivaren. Ook dit heeft, zoals ik U zal uitleggen, met valutakoersveranderingen te maken. Nu ga ik $U$ uiteraard niet vertellen wanneer $U$ op de meest voordelige manier $U w$ vakantie-vreemdgeld kunt kopen en evenmin op welke wijze $U$ in derivaten kunt gaan handelen, miljoenen aan bonussen kunt incasseren en, het belangrijkste, niet tegen de lamp zult lopen. Zoals in de aankondiging staat vermeld zal ik wél met $U$ spreken over Valutaire winden rond de jaarrekening, hetgeen betekent dat ik enige opmerkingen zal maken over de betekenis van de onrust op het valutafront en de gevaren van het handelen in derivaten voor de jaarverslaggeving. 


\section{De onrust op het valutafront ${ }^{4}$}

Classificeren vormt de start van veel onderzoek, het zichtbaar maken van de gemeenschappelijke kenmerken en het zichtbaar maken van de wezenlijke verschillen. Wanneer wij praten over vreemde valuta's zijn er met betrekking tot de jaarrekening een tweetal classificaties van belang: een classificatie op basis van de verschillende bewegingen van valuta's en een classificatie op basis van de aard van het risico dat een onderneming door deze veranderende valuta's loopt.

Op grond van deze bewegingen kunnen we een drietal hoofdgroepen onderscheiden:

- een eerste groep van valuta's waarvan de onderlinge verhoudingen (de prijs of de koers) ook op de lange termijn nauwelijks wijzigt. Een goed voorbeeld hiervan vormen de valuta's van de landen die lid zijn van het EMS (Europese Monetaire Stelsel). Deze landen hebben onderling afgesproken dat als de marktomstandigheden de koers buiten bepaalde grenzen (de 'slang') duwen de EMS-landen op deze markt ingrijpen door valuta's te kopen of te verkopen, de rente te verlagen of te verhogen, etc. Voorbeelden van deze groep van valuta's zijn de Nederlandse gulden, de Duitse Mark en de Belgische Frank.

Zie Koersverloop DM-Mark op de volgende pagina.

Wanneer de markt echter te zeer verstoord wordt en ingrijpen het dempen van een bodemloze put wordt, worden de 


\section{Koersverloop D-Mark}

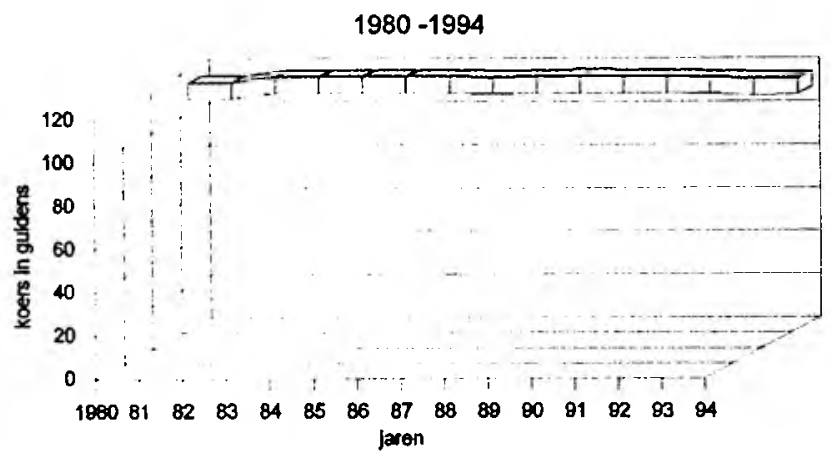

betreffende valuta tijdelijk (dat echter wel lang kan duren) buiten het stelsel geplaatst. Een goed voorbeeld hiervan is het Engelse Pond. Ze komen dan in de volgende groep terecht.

- een tweede groep van valuta's omvat die valuta's waarvan op grond van marktverhoudingen de koers nu eens stijgt en dan weer daalt. In vakkringen noemen we dat een 'walking around valuta', de koers slingert zich om een denkbeeldige evenwichtslijn. Voorbeelden hiervan zijn de Amerikaanse dollar en, ik noemde hem al, het Engelse Pond.

Zie Koersverloop USdollar op de volgende pagina. 


\section{Koersverloop US-dollar}

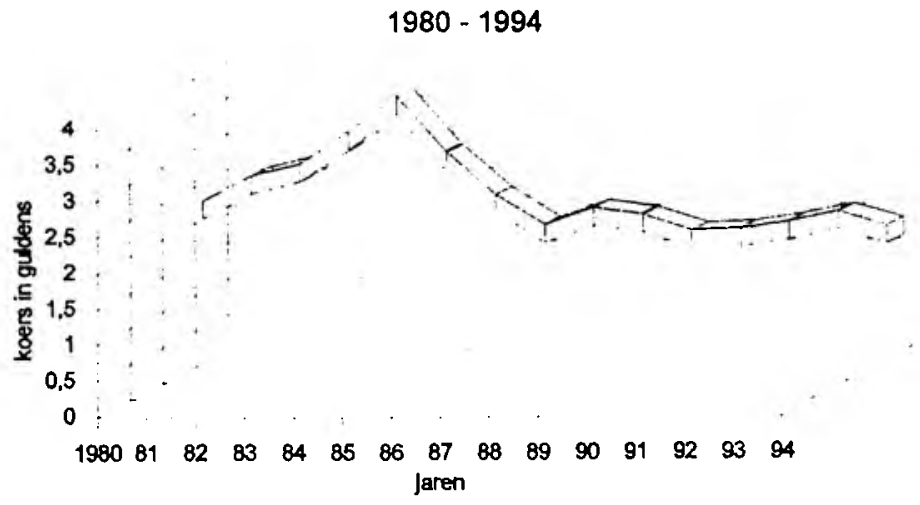

Op het eerste gezicht lijkt het of het verschil tussen deze groep en de vorige slechts bestaat uit de omvang van de schommelingen; bij deze tweede groep groot, bij de eerste groep zeer gering. Bij nadere beschouwing blijkt echter dat er ook beweging zit in wat ik aanduid met evenwichtskoers, deze blijkt steeds op een lager niveau te komen liggen. ${ }^{5}$ De mogelijke consequenties hiervan voor de jaarrekening zal ik verderop uitwerken.

- volledigheidshalve moet ik een derde groep van valuta's noemen namelijk die van de hyperinflatielanden. Deze valuta's bevinden zich in een toestand van voortdurende vrije val. Een goed voorbeeld hiervan is de Braziliaanse munt die nu eens Crusado en dan weer Cruzeiro genoemd wordt. 


\section{Koersverloop Braziliaanse munt}

$1980-1994$

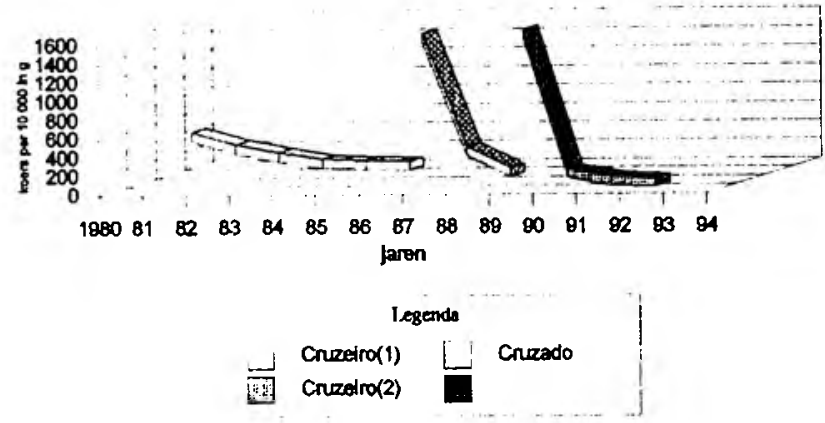

Noot: rowcl eind 1993 en eind 1994 waren nieuwe munten ingevoerd. Doordat die van 1993 het geen jaar heeft uitgehouden kon deze niet in de grafiek worden weergegeven. De huidige munt is de Cruzeiro Real (met een aan de USdollar beoogde koppeling) waarvan de koers per 3ldecember 19941.49 gulden per stuk was.

Zoals $U$ ziet wordt er steeds wanneer de koers van de munt tot bijna nul is gedaald, een nieuwe munteenheid in het leven geroepen, een maatregel die overigens slechts tijdelijk werkt. Naar de gevolgen van deze groep van valuta's voor de jaarrekening heb ik tijdens mijn RL-periode onderzoek verricht. In de geschreven tekst staat de betreffende publikatie genoemd. ${ }^{6}$ Ik ga er hier niet verder op in.

Een tweede classificatie betreft de aard van het risico dat veroorzaakt wordt door de veranderende valutakoersen. Ook hier kunnen we drie groepen onderscheiden: 
- in de eerste plaats is er het economische risico. Dit risico ontstaat door een onevenwichtigheid tussen de in- en uitgaande geldstromen in de verschillende valuta's. Een klassiek voorbeeld is de produktie van Philishaves in Drachten (een uitgaande kasstroom in guldens) waarvan een belangrijk deel op de Amerikaanse markt wordt afgezet (een inkomende geldstroom in dollars). Indien de koers van de dollar daalt komt de winstmarge onder druk te staan. Een belangrijk deel van de commentaren op de huidige valutaonrust heeft betrekking op dit economische risico. In concreto een concurrentienadeel voor de landen met een harde valuta (Nederland, Duitsland, Japan), een concurrentievoordeel voor de Verenigde Staten door de dalende koers van de dollar.

- in de tweede plaats is er het conversie- of transactie risico. $\mathrm{U}$ zult dat zelf wel eens aan den lijve ondervonden hebben indien $U$ voor $U w$ vakantie een land heeft gekozen met een snel fluctuerende valuta (bijvoorbeeld Italië, Spanje of Griekenland). $U$ heeft Italiaanse lires gekocht voor een bepaalde prijs, Uw vakantie is wat goedkoper uitgevallen en $U$ verkoopt de overgehouden lires weer aan de bank. U zult dan waarschijnlijk een conversieverlies lijden dat niet alleen verklaard kan worden uit het verschil tussen de door de bank gehanteerde aan- en verkoopkoersen.

- in de derde plaats kennen we het vertaalrisico. Indien een Nederlandse onderneming een ander bedrijf (een deelneming) in het buitenland heeft, moeten de balans en de winst- en verliesrekening die ter plaatse in een vreemde valuta zijn opgesteld, vertaald (omgerekend) worden naar guldens. Dit 
is onder andere nodig voor de opstelling van een geconsolideerde jaarrekening. Wanneer de koers van de betreffende valuta sinds de vorige 'vertaling' is gewijzigd, ontstaat er een verschil tussen de huidige en de voorgaande omrekening. We duiden dit verschil aan met 'omrekeningsverschil'. Deze omrekeningsverschillen zijn in wezen potentiële conversieverschillen. Zodra de deelneming van de hand wordt gedaan moeten de ter plekke ontvangen vreemde valuta immers weer worden omgezet, geconverteerd in guldens.

Een winst- en verliesrekening geeft weer welke bedragen een onderneming in de verslagperiode armer of rijker is geworden. De verschillen als gevolg van het economische risico en het conversierisico worden dan ook op de winst- en verliesrekening verantwoord. ${ }^{7}$ De verschillen als gevolg van het vertaalrisico worden echter in overgrote meerderheid rechtstreeks op het eigen vermogen gemuteerd en blijven dus buiten de winst-en verliesrekening. In de Verenigde Staten is dit voorgeschreven, binnen de Europese Unie wordt dit aanvaardbaar geacht. Er is echter een belangrijk verschil. In de Verenigde Staten worden verschillen voorlopig niet op de winst- en verliesrekening verantwoord maar worden ze op de balans binnen het eigen vermogen 'geparkeerd'. Ze worden pas op de winst- en verliesrekening verantwoord als deze verschillen zijn gerealiseerd, dat wil zeggen wanneer de betreffende deelneming is verkocht. De vertaalverschillen worden dan conversieverschillen. Niet aldus in de Europese Unie, in de meeste gevallen wordt niet teruggekomen op de vertaalverschillen en blijven ze een structurele aantasting van het eigen vermogen. ${ }^{8}$ 
Ik heb $\mathrm{U}$ nu voldoende voorinformatie gegeven om met mij een tweetal opmerkingen te overdenken. De eerste heeft betrekking op het saldo afgeboekte vertaalverschillen binnen het eigen vermogen tegen de achtergrond van de steeds verder wegzakkende evenwichtskoers van bijvoorbeeld de Amerikaanse dollar of het Engelse Pond. De tweede kritische opmerking betreft de valuta waarin wij in Nederland onze financiële jaarrekeninginformatie plegen uit te drukken. Dit biedt ongekende mogelijkheden om met name het eigen vermogen rooskleuriger voor te stellen.

Er bestaat een frappante relatie tussen de ontwikkeling van de koers van bepaalde valuta's die een sleutelrol spelen en het saldo omrekeningverschillen binnen het eigen vermogen. Om dit te illustreren neem ik het jaarverslag van 'Shell'.

\section{Valutakoers en vertaalverschillen Shell}

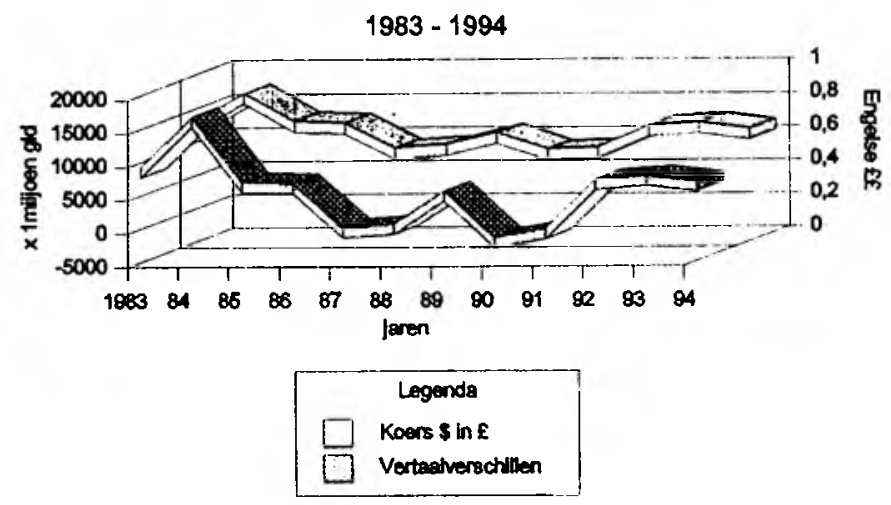


Ik heb in deze grafiek niet de koers van de USdollar, uitgedrukt in Nederlandse guldens, gebruikt maar de koers van de USdollar in relatie tot het Britse Pond. Ik heb de US-dollar genomen omdat de 'oliewereld' dollar-georiënteerd is. Shell rapporteert in haar Nederlandse jaarverslag weliswaar in guldens maar de omrekening heeft in eerste instantie naar Britse ponden plaatsgevonden. De omrekening naar guldens is in wezen secundair De causale relatie tussen valutakoers en omrekeningsverschillen is groot. ${ }^{9}$ Het is belangrijk dergelijke causale relaties te kennen omdat op deze wijze het voorspellend vermogen van de jaarrekening aanzienlijk vergroot wordt. Op basis van dit verband en kennis van de valutakoers op een bepaald moment kan men een tamelijk nauwkeurige voorspelling maken van het bedrag omrekeningsverschillen op dat moment. Ik weet bijna zeker dat Shell niet op elk moment haar saldo vertaalverschillen kent. Laat ik even stellen dat dit een voorbeeld is waarmede zeker niet gezegd is dat het belangrijk zou zijn deze vertaalverschillen op ieder moment te kennen. Maar dergelijke exercities zijn ook voor andere belangrijke informatie mogelijk. Naar mijn mening wordt nog te weinig met dit soort voorspellingstechnieken gewerkt. Geen belangstelling, geen tijd of gebrek aan specialistische kennis?

Verder wijs ik er op dat indien de koers van een sleutelvaluta structureel daalt er ook een structureel debet-bedrag vertaalverschillen op de balans ontstaat. Dit debet-bedrag moet bij afstoting van de betreffende deelneming als verlies genomen worden. Dit kan een belemmering zijn om de betreffende deelneming af te stoten. De administratieve regels voor de verwerking kunnen op deze wijze een gezonde bedrijfsvoering in de weg staan. Ook 
moet de vraag gesteld worden of binnen de Europese verslaggevingscultuur niet op dit latente verlies geanticipeerd moet worden.

Het tweede probleem is eigenlijk een 'opportunity' die de Nederlandse ondernemingen (behalve Shell misschien, maar Shell is met haar jaarverslag toch een beetje een vreemde eend in de bijt $\left.{ }^{10}\right)$ kennelijk nog niet hebben ontdekt maar misschien komt dat nu. Boekhouders/controllers en accountants zijn op hun gebied ware tovenaars, soms kunnen zij van verliezen winsten maken en toch binnen de regels blijven. Ik zal $U$ dit laten zien aan de hand van de keuze van valuta waarin de jaarrekening wordt opgesteld.

Sinds kort is in de Nederlandse wetgeving de mogelijkheid opgenomen om de jaarrekening in een vreemde valuta op te maken (dat is dus een valuta anders dan de gulden). "Voorwaarde is dat de werkzaamheden van de rechtspersoon of de internationale vertakking van zijn groep dat rechtvaardigt. Het argument om een andere valuta dan de gulden te kiezen wordt hier dus door de wetgever aangereikt, welke Nederlandse onderneming van enige betekenis voldoet niet aan deze voorwaarde?

Een heel klein theoretisch voorbeeldje illustreert dit nog duidelijker. Stel er is een Nederlandse onderneming met een deelneming van 100 gulden in Nederland en met een deelneming van 100 vreemde valuta in een vreemd land. Laten we gemakshalve uitgaan van een koers per 1 januari 1994 van 1 vreemde valuta is 1 gulden. Stel verder dat de koers van deze vreemde valuta per 31 december 1994 gedaald is tot 1 vreemde valuta is 0.8 gulden (en dus ook 1 gulden is 1.25 vreemde valuta). Wanneer we als rapporteringseenheid de gulden nemen is de 'waarde' van 
de twee deelnemingen samen gedaald van $200(100+100)$ tot $180(100+80)$ gulden. Wanneer we als rapporteringseenheid echter de vreemde valuta nemen dan is de 'waarde' van de twee deelnemingen samen gestegen van $200(100+100)$ tot $225(100$ $+125)$ vreemde valuta. Het 'getrouwe beeld' kent kennelijk verschillende gezichten.

De conclusie is dat naarmate de valuta waarin gerapporteerd wordt zwakker is (in relatie tot de gulden) de vertaalverschillen het geringst zijn en zelfs kunnen omslaan in een 'winst". Het verdient derhalve aanbeveling op grond van artikel 362 lid 7 een 'vreemde valuta' als rapporteringsvaluta te kiezen. Het argument om dit te doen komt het meest geloofwaardig over indien de betekenis van de gekozen valuta een centrale rol speelt of verwacht wordt te spelen in de wereldhandel. De keuze zal dan ook moeten vallen op de dollar of de ecu. Het kiezen van andere zwakke valuta's zoals de lire of het pond zal in het algemeen niet te rechtvaardigen zijn.

Tot zover deze excursie naar de tovenaars- of liever gezegd de goochelwereld van international accounting. Ook hier geldt dat je met je tovenaars- en goochelkunsten de werkelijkheid slechts anders kunt tonen dan ze is. De werkelijkheid blijft de werkelijkheid maar wat is de werkelijke werkelijkheid? Of zoals het in ons vakjargon heet: wat is het getrouwe beeld?

$\mathrm{Nu}$ een ander aspect van vreemde valuta. Ik wilde het met $\mathrm{U}$ hebben over de nieuwe financiële instrumenten, de off balance financiering, de derivaten of hoe ze ook genoemd worden. In wezen gaat het om handel in financiële risico's. En U weet het 
misschien wel, waar financiële risico's zijn, zijn er ook mogelijkheden om winst of verlies te maken. De financiële risico's kunnen in wezen 'alles' omvatten maar in de praktijk gaat het om renterisico's en valutarisico's. In het vervolg beperk ik mij tot de laatste alhoewel er meestal een duidelijke relatie is tussen renteen valutarisico. Dat dergelijke zaken fout kunnen gaan hebben we kunnen zien aan de Britse bank Baring, die inmiddels door de Nederlandse Internationale Nederlanden Groep (JNG) is overgenomen. $U$ zult daarover in de krant gelezen hebben en misschien niet geheel en al begrepen hebben wat er gaande was. Daarom eerst wat algemene informatie over de derivaten (ik houd me nu maar aan deze benaming). Daarna zal ik nog wat opmerkingen maken over de externe berichtgeving rond deze derivatenhandel.

De derivaten kun je in twee duidelijk van elkaar te onderscheiden situaties gebruiken. De ene situatie duid ik aan met de nutfige functie, de andere situatie met de gevaarlijke toepassing.

\section{De nuttige functie}

De doelstelling van de meeste ondernemingen wordt gerealiseerd door het benutten van prijsverschillen die op eenzelfde tijdstip bestaan tussen verschillende markten, de zogenaamde gelijtijdige prijsverschillen. Deze verschillende markten kunnen geografisch verschillend zijn: inkoop van wijn in grote hoeveelheden in Frankrijk tegen lage prijzen en verkoop in Nederland in kleine hoeveelheden tegen hoge prijzen (Albert Heijn). Een ander voorbeeld: het kopen van onderdelen op een bepaalde markt, deze assembleren en vervolgens het produkt als televisie op een andere markt verkopen. Een onderneming loopt echter 
niet alleen gelijktijdige prijsrisico's, ze wordt ook geconfronteerd met volgtijdige prijsrisico's. Deze kunnen de winst behaald door het benutten van gelijktijdige prijsrisico's, aantasten. Een voorbeeld. Albert Heijn importeert wijn uit Frankrijk en heeft daarvoor op 2 januari een contract afgesloten op basis van een bepaalde prijs uitgedrukt in Franse francs. Op basis van de koers op 2 januari heeft AH zijn verkoopprijs in guldens vastgesteld. $\mathrm{Nu}$ blijkt echter dat de koers van de Franse franc op 1 juni, de datum dat een zending betaald moet worden, gestegen is. De wijn is in guldens gemeten dan duurder geworden en het is de vraag of de verkoop nog winstgevend is. Even terug naar het eerste deel van mijn afscheidscollege, er is hier sprake van een economisch risico.

Is daar iets aan te doen? Ja, met behulp van een van de derivaten. De meeste derivaten bestaan uit één van de volgende basisvormen of een of andere combinatie daarvan. De eerste basisvorm is het termijncontract: Albert Heijn koopt op 2 januari de benodigde francs en laat deze op 1 juni leveren. $\mathrm{AH}$ heeft met deze termijntransactie zekerheid gekocht maar profiteert ook niet van eventuele voordelen als de koers niet stijgt maar daalt. Bij de tweede basisvorm kun je wel profiteren van eventuele voordelige ontwikkelingen, men sluit dan een optiecontract af. Albert Heijn koopt op 1 januari het recht om voor een bepaalde koers op 1 juni een bepaalde hoeveelheid Franse francs te kopen. Is dit voordelig (de koers is gestegen) dan maakt ze hiervan gebruik, is het voor haar nadelig (de koers is gedaald) dan maakt ze geen gebruik van het contract. Een derde basisvorm wordt gevormd door de swaps. Hierbij worden valuta's geruild tussen partijen die een tegengestelde behoefte aan bepaalde valuta hebben. 
Ik sprak van een nuttige functie omdat de 'gekochte' derivaten er toe leiden dat bepaalde volgtijdige risico's worden gedekt, in het Engels wordt dit aangeduid met hedging. Veelal spelen banken hierbij een bemiddelende rol, ze brengen partijen met tegengestelde behoeften bij elkaar en nemen een eventueel verschil tussen vraag en aanbod op een bepaald moment voor eigen rekening. Terecht brengen ze voor deze diensten een vergoeding in rekening die in zijn algemeenheid als een rente- en kostenvergoeding kan worden gekarakteriseerd.

Voor wat de externe berichtgeving betreft zijn er een tweetal problemen. ${ }^{13} \mathrm{Bij}$ hedging kunnen er een tweetal posities worden onderkend. De ene positie (in het Duits aangeduid met 'Grundgeschäft') waarop het koersrisico wordt gelopen en de andere (het 'Sicherungsgeschäft') waarop een tegengesteld koersrisico wordt gelopen. Wat je op de ene positie wint, verlies je op de andere positie en omgekeerd. Het is derhalve logisch dat beide posities gelijk worden gewaardeerd zodat op geen enkel moment een resultaat wordt getoond. En daar verzet de wetgeving in de Europese Unie zich in beginsel tegen. Deze gaat uit van een individuele waardering ('Einzelbewertung') en een uiterste voorzichtigheid bij het bepalen van de uitkeerbare winst. Dit leidt er in concreto toe dat tijdens de looptijd van het risico wel een verlies op de ene positie wordt getoond maar dat de corresponderende winst op de andere positie pas wordt getoond op het moment dat het risico afloopt. ${ }^{14}$ Deze discussie speelt met name in Duitsland maar ook wel in Nederland.

Het tweede berichtgevingsprobleem betreft de balanspresentatie. De beoordeling van een onderneming op basis van de jaarrekening richt zich in hoofdzaak op rentabiliteit, liquiditeit en solva- 
biliteit. Het hier gesignaleerde probleem gaat om de solvabiliteit: is een onderneming in staat aan haar financiële verplichtingen te voldoen ook op de lange termijn. Van oudsher wordt daar de verhouding tussen het eigen en het vreemd vermogen gehanteerd. ${ }^{15}$

$\mathrm{Bij}$ de meeste derivaten wordt een aantal geldstromen opgewekt. Zo gaat bij de afwikkeling van een valutatermijncontract een bepaalde hoeveelheid eigen valuta naar de contractpartner terwijl er een bepaalde hoeveelheid vreemde valuta naar de onderneming stroomt. Zouden bij het afsluiten van een contract beide potentiële geldstromen in de balans worden opgenomen, dan verslechtert de solvabiliteitsratio. Het vreemde vermogen wordt immers groter. ${ }^{16} \mathrm{Bij}$ de banken die op basis van deze solvabiliteitsratio werden beoordeeld door de Centrale Banken en daardoor in hun activiteiten werden beperkt is jaren geleden de gedachte opgekomen om deze derivaten buiten de balans te houden. Vandaar de naam 'off balance instrumenten'. Toen dit ingang vond bij de banken kwam de gedachte op de verkoop van derivaten aan ondernemingen te stimuleren met het 'off balance' argument als verkoopleuze. Ook werd toen de benaming 'nieuwe financiële instrumenten' bedacht alhoewel het in wezen ging om reeds lang bestaande produkten. ${ }^{17} \mathrm{De}$ on/off balance strijd is nog volop gaande. Een aantal actuele frontposities van de strijdende partijen mogen niet onvermeld blijven:

1. bij de banken is een nieuwe solvabiliteitsratio ontwikkeld voor het toezicht van de centrale banken waarbij on en off balanceposities gelijk worden behandeld. Schoorvoetend vindt deze nieuwe ratio ook ingang in de externe berichtgeving van banken. ${ }^{18}$ Het zou naar mijn mening overweging 


\section{lahtare winden rond de aarrehenm.x}

verdienen deze nieuwe solvabiliteitsratio in wellicht aangepaste vorm ook voor andere ondernemingen dan banken in te voeren

2 in de IISA en bij het IASC is voorlopig een tussenoplossing gekozen "De off balance posten mogen buiten de balans blijven maar moeten uitgebreid worden vermeld in de 'toelichting' De gebruikers van jaarrekeningen kunnen ze dan naar behoefte al dan niet alsnog verwerken in de balans Uiteraard is dit geen gebruikersvriendelijke oplossing

3. de principiele vraag is wat op de balans opgenomen moet worden: rechten en verplichtingen of risico's. Bij de voorstanders van een off balance verwerking bestaat de mening dat het risico bepalend is. Naar mijn mening is dit een onjuiste stellingname, het gaat om de rechten en verplichtingen. Het risico of in het algemeen de kwaliteitsaspecten van een balanspost vormen een tweede dimensie. Het vermelden van deze kwaliteit behoort in de toelichting plaats te vinden.

Dit was de nuttige tak van de derivatenfamilie, nu een paar opmerkingen over de gevaarlijke toepassing.

\section{De gevaarlijke toepassing}

Wanneer derivaten niet worden gebruikt om bestaande risico's af te dekken maar om risico's te zoeken en daarmee geld te verdienen, speculeert men en is er sprake van een gevaarlijke toepassing. Derivaten worden dan een soort flipperkast voor financiële gokverslaafden. $U$ ziet ze wel eens op de televisie wanneer er beelden worden vertoond van meestal wat jongere 
personen die handel drijven op financiële markten. Men bedient minstens twee telefoons tegelijk, 'spreekt' een voor ons onbegrijpelijke gebarentaal tegen de achtergrond van een groot aantal beeldschermen.

Hoe fout het kan gaan wanneer men op de derivatenmarkt speculeert heeft men kunnen zien aan het geval Barings. De Van Den Boomgroep heeft een inventarisatie gemaakt van het aantal affaires rond de toepassing van derivaten en van de oorzaken die aan het fout-gaan ten grondslag lagen. ${ }^{20}$ Er blijkt een explosieve stijging van het aantal affaires: in de jaren 1987 - 1991 waren er twee affaires, in 1993 drie en in 1994 waren er negen affaires. Het geschrift dateert van maart 1995 en toen waren er al twee gevallen bekend (Barings en Chemical Bank). Mocht deze tendens zich voortzetten dan zou 1995 het huidige topjaar 1994 wel eens kunnen overtreffen. Of heeft men intussen geleerd van het verleden? Het lijkt er niet op want veel banken voorspellen een verdere groei van de handel in en de winst op derivaten. En geldt ook hier niet 'your profit is my loss'?

Wat de oorzaken betreft blijkt uit het Van Den Boom-onderzoek (bij enkele affaires was er sprake van een cumulatie van oorzaken) dat in drie gevallen sprake was van fraude, terwijl men in vier gevallen buiten het boekje was gegaan (de gestelde limieten waren overschreden). In zeven gevallen speelde ondeskundigheid een belangrijke rol en in twaalf gevallen was er sprake van 'missers'. Onder 'missers' moet dan kennelijk worden verstaan: door deskundige personen binnen hun bevoegdheden afgesloten transacties die een min of meer catastrofaal verlies hebben opgeleverd. Je zou dit het onvermijdbare dan wel geaccepteerde risico van het vak kunnen noemen. Hierbij wijs ik er 
op dat in het onderzoek van de Van Den Boomgroep alleen die affaires zijn behandeld die tot grote verliezen hebben geleid Waar sprake was van overschrijding van de bevoegdheden of van missers die slechts tot kleinere verliezen of misschien wel winsten hebben geleid komen deze niet naar buiten. Kennelijk ligt de scheidslijn bij de uitkomst: winst of verlies en niet bij goed of slecht beleid (tenzij men natuurlijk goed en slecht ook weer vertaald naar termen van goed $=$ winst en slecht $=$ verlies) Tegen de affaires zoals opgenomen in het onderzoek is nauwelijks iets te doen tenzij men de derivatenhandel in de gevaarlijke toepassing zou verbieden dan wel dat men de regels en het toezicht op de naleving daarvan aanzienlijk verscherpt. Voor Nederland is de afschaffing maatschappelijk niet acceptabel (de afschaffing van de Krasloterij is dat al niet) en wat de verscherping van de regels en het toezicht daarop ${ }^{21}$ betreft is enige tijd geleden hier op dezelfde plaats de stelling verdedigd 'Nederlanders hebben aan twee dingen een grote hekel: aan regels en aan zaken die niet wettelijk geregeld zijn.' ${ }^{22}$ Dit verschijnsel is dacht ik voor iedereen dagelijks waarneembaar. Hierbij moet nog worden opgemerkt dat indien affaires zoals die van Barings maatschappelijk netjes worden opgelost ( er vallen geen ontslagen buiten de directie en de cliënten komen niets tekort) de roep om preventieve maatregelen nauwelijks gehoord wordt. ${ }^{23} \mathrm{Het}$ enige wat kan en moet gebeuren is dat de ondernemingen zich expliciet uitspreken over de omvang en de aard van de risico's die zij wensen te lopen, over de interne maatregelen die zij genomen hebben en dat zij verklaren dat ook slechts binnen deze grenzen is gehandeld. Laten wij eens kijken welke bijdrage de externe berichtgeving hieraan kan leveren. De vraag kon tot voor kort slechts beantwoord worden met een teleurstellend 


\section{I'alutaire winden rond de jaarrekening}

'niets'. De externe berichtgeving heeft immers slechts tot taak de uitkomsten van het beleid, inclusief de 'affaires' te tonen En aangezien deze externe berichtgeving altijd ex post (achteraf) en met grote intervallen is (jaarlijks, soms ook halfjaarlijks of per kwartaal), heeft deze berichtgeving in het geval van ernstige affaires in wezen een zelfde functie als een overlijdensadvertentie.

Er is echter thans een ontwikkeling met name in de USA en in Groot Brittannië op gang gekomen. ${ }^{2+}$ Het navolgende is een persoonlijke interpretatie en combinatie van de Amerikaanse en Britse voorstellen, het gaat hier immers om de door mij gewenste invloed op de Nederlandse situatie. Werd in de externe berichtgeving uitsluitend dan wel vooral verslag gedaan over de uitkomsten van het gevoerde beleid, je zou kunnen zeggen een proces verbaal, thans moet ook daarin een verklaring worden opgenomen over de inhoud en de grenzen van het te voeren beleid en de verantwoordelijkheden daarvoor en dat het beleid zich binnen deze grenzen heeft afgespeeld. Het gaat hier vooral om het nauwelijks in het Nederlands te vertalen begrip 'Corporate Governance'. De nadruk ligt op het vastleggen (en publiceren) van de bevoegdheden en de verantwoordelijkheden van de Raad van Bestuur en van de Raad van Commissarissen en de Externe Accountant in hun onderlinge relaties. Op deze wijze is het beter mogelijk een inschatting te maken van de risico's die men als belanghebbende bij een onderneming loopt en op grond daarvan te beslissen over het aangaan, aanhouden of beëindigen van een relatie met de betreffende onderneming. Belangrijk is ook de informatie welk deel van de beloning van het management als vast is te beschouwen en welk deel afhankelijk is van 
de geleverde prestatie. De externe accountant moet in de jaarrekening een verklaring opnemen in welke mate de mededeling van het management inzake de corporate governance, voorzover deze door de accountant controleerbaar is, juist is. De accountant is daarmee ook partij geworden.

De ontwikkelingen in de richting van een corporate governanceverklaring zijn nog maar nauwelijks op gang gekomen In $\mathrm{Ne}$ derland is een eerste stap gezet door in de nieuw voorgestelde accountantsverklaring tot uitdrukking te brengen waarvoor het management en waarvoor de accountant verantwoordelijk is. Dit is een eerste stap die logischerwijs gevolgd moet worden door het voorschrijven van een corporate governance verklaring van het management.

Daarmee wordt het duidelijker in welke gevallen de externe accountant wel of niet (mede-)verantwoordelijk en dus ook (mede-)aansprakelijk is voor bepaalde 'affaires'. Hij zal met name aansprakelijk zijn indien het gaat om affaires die veroorzaakt zijn door zwakheden in en overschrijding van de corporate governance-grenzen voorzover deze door de controlerende accountant niet gemeld zijn in zijn verklaring en voorzover deze zwakheden en/of overschrijdingen voor de accountant controleerbaar was. Een en ander betekent in de parktijk een uitbrei-

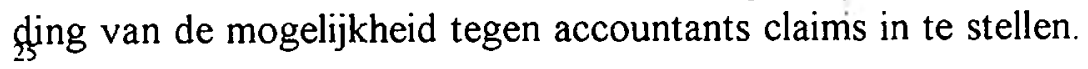

In tegenstelling tot de accountants die aangesproken worden voor schadevergoeding ben ik van mening dat deze claims voorzover ze uit de controlepraktijk voortvloeien een nuttige functie hebben. De markt voor accountantscontrolewerkzaamheden in 
Nederland (en in vele andere landen) kenmerkt zich door 'monopolistische concurrentie'. De omvang van de markt is zowel gegarandeerd (wettelijk verplichte controle) als beperkt (er komen jaarlijks slechts weinig te controleren ondernemingen bij). Op een dergelijke markt kun je je slechts onderscheiden door kwaliteit en prijs. Gegeven het feit dat we in de praktijk slechts goedkeurende verklaringen kennen met bijna uniforme bewoordingen ${ }^{26}$ speelt het kwaliteitsaspect nauwelijks: voor de gebruiker is elke (goedkeurende) verklaring gelijk. Het enige waarmede de accountant dan nog kan concurreren is de prijs. Gegeven de markt voor accountantscontrole: een nagenoeg gelijkblijvende vraag en een geleidelijk stijgend aanbod (ieder jaar nog studeren er meer accountants af dan er met pensioen gaan) leidt dit tot dalende prijzen. De accountants kunnen deze ontwikkeling slechts volgen door steeds minder uren aan controle te besteden. Voorzover dit niet wordt opgevangen door efficiency-verbeteringen, die ook niet tot in het oneindige kunnen doorgaan, leidt dit tot een lagere kwaliteit en ook tot een toenemend aantal claims. Deze claims moeten markttechnisch gezien worden als een correctie op de contractueel bedongen vergoeding zodat het saldo een marktprijsachtig karakter krijgt: lage kwaliteit $\Leftrightarrow$ veel claims $\Leftrightarrow$ lage marktprijs. En hoge kwaliteit $\Rightarrow$ weinig of geen claims $\Leftrightarrow$ hoge marktprijs. Nederland wordt niet zonder reden tot de marktgeoriënteerde landen gerekend alhoewel het proces, zoals we bij de accountantscontrole zien, nogal omslachtig verloopt. ${ }^{27}$

$\mathrm{Na}$ deze afdwaling naar de Corporate Governance en de aansprakelijkheid van accountants nog enkele opmerkingen over de externe berichtgeving rond de gevaarlijke toepassing van deriva- 
ten. Er valt een tendens te bespeuren om de derivaten in de gevaarlijke toepassing (speculatie) in de berichtgeving op dezelfde manier te behandelen als de derivaten in hun nuttige toepassing (hedging). ${ }^{28}$ Naar mijn mening is dat niet juist omdat het karakter fundamenteel verschilt. Dit betekent onder andere (ik duid de gevaarlijke toepassing gemakshalve aan als speculatie):

1. Resultaten op in het jaar afgewikkelde speculatieve transacties dienen afzonderlijk getoond te worden in de winst- en verliesrekening. Afzonderlijke vermelding van positieve en negatieve resultaten is nodig om inzicht te krijgen in het risico dat gelopen is.

2. Resultaten op de per balansdatum nog lopende transacties moeten voorzichtig benaderd worden: verliezen per balansdatum nemen en winsten pas nadat ze gerealiseerd zijn. ${ }^{29}$ Een portefeuille-benadering, dat wil zeggen zoveel mogelijk winsten en verliezen compenseren en slechts het saldo verantwoorden is alleen toegestaan voorzover er een oorzakelijk verband bestaat tussen de te compenseren posten. Je zou hier kunnen denken an de mogelijkheid toe te staan dat verliezen op dollarposities met winsten op andere dollarpositie; worden gecompenseerd.

3. Ook bij speculatieve posities moeten rechten en verplichtingen beide op de balans worden opgevoerd. Ook hier dus geen off balance verantwoording. De risico's op deze rechten en verplichtingen moeten een plaats vinden in de toelichting. 
Of dit haalbare suggesties zijn of anders gezegd of ze door de Raad voor de Jaarverslaggeving als maatschappelijk aanvaardbare normen zullen worden bestempeld, is nog maar de vraag. Zolang er nog iets te verbergen is zal men dit in 'goed overleg' blijven toestaan. Totdat het een verloren zaak is zoals bij de affaires die in het onderzoek van de Van Der Boom Groep zijn genoemd?

Ik ben hiermede aan het eind gekomen van mijn afscheids-overzichtscollege. Lang niet alle valutaire winden rond de jaarrekening zijn aan de orde gekomen. Maar misschien heeft $U$ er iets van opgestoken en begrijpt $U$ alle berichten en alle affaires rond de vreemde valuta een beetje beter dan hiervoor. Hopelijk heb ik wel mijn eigenlijke doelstelling bereikt en bent $U$ nu ook van mening dat externe berichtgeving een mooi en interessant vak is omdat het niet blijft staan bij de enge grenzen van het vak zelf. U begrijpt dan ook waarom ik hier zo'n fijne tijd heb gehad. 


\section{Noten}

l Samen met collega Langendijk van de L vA doe ih onderzoek naar de huidige toepassing $>$ an de actuele waarde in de jaarverslagen van Nederlandse ondernemingen De resultaten zullen gepubliceerd worden in Jaar in - jaar uit 9

2 Over dit onderwerp zal ik op het komende FMA-congres een inleiding houden

3 Door het Limperg Instituut is een onderzoeksproject Kwaliteit van de externe financiele verslaggeving in $\mathrm{Ne}$ derland, gestart. Ik heb op persoonlijke titel medewerking aangeboden.

4. Over dit onderwerp publiceerde ik uitgebreid in Vergelijkbaarheid van jaarrekeningen in nationaal en internationaal perspectief ('Vreemde valuta in de jaarrekening'), Kluwer Bedrijfswetenschappen 1990.

5. De evenwichtskoers van de Amerikaanse dollar lag zo rond 1950 nog op fl. 3.60, die van het Britse pond zelfs op hfl. 12.00

6. Hyperınflatielanden in de geconsolideerde jaarrekening, in Jaar in - jaar uit 8 onder redactie van M.N. Hoogendoorn en R. van der Wal, Wolters-Noordhoff 1993 
7. De resultaten uit hoofde van het economische risico worden niet afzonderlijk vermeld maar meestal in de toelichting genoemd: 'als gevolg van de dalende dollarkoers was de omzet in guldens a\% lager'. De resultaten uit hoofde van het conversierisico zijn in beginsel wel afzonderlijk te traceren in de winst- en verliesrekening. De ondernemingen geven er om hen moverende redenen vaak de voorkeur aan deze verschillen te laten 'onderduiken'.

8. De theoretische mogelijkheid is aanwezig dat de vertaalverschillen al dan niet per saldo voordelig zijn. Omdat de Nederlandse gulden één der sterkste valuta ter wereld is gaat het in de Nederlandse praktijk echter bijna steeds om dalende valutakoersen. Bovendien is bijna altijd sprake van een per saldo positieve investering.

9. Voor de liefhebbers: de correlatiecoëfficient van de relatie vertaalverschillen : \$-koers uitgedrukt in $£$ is 0.9875 . De relatie tussen de vertaalverschillen en de $\$$ koers uitgedrukt in glds is laag, namelijk 0.781 . Er is nauwelijks een relatie tussen de vertaalverschillen en de koers van het $\mathfrak{E}$ uitgedrukt in glds (correlatie coëfficient is 0.3441 ).

10. Zie in dit verband ook de bespreking van de drie Brits-Nederlandse concerns (Shell, Unilever en Reed Elsevier) in H.L. Brink en W.F.J. Buijink: De relatie tussen de vennootschappelijke en de geconsolideerde jaarrekening in Jaar in - jaar uit 8, Kluwer Bedrijfswetenschappen 1994).

11.BW2, Titel 9 , art. 362 lid 7. 
12 Boot, Ligterink eri Scholtens maken in 'De ondergang van Barings (ESB van 15 maart 1995) eenzelfde onderscheid De nuttige functie noemen zij relatie-georienteerd, de gevaarlijke functie noemen zij handelsactiviteiten

13 Het eerste probleem, dat van de 'Bewertungseinheiten' wordt uitgebreid behandeld in M. Göttgens. Hedge Accounting, Betriebswirtschaftliche Forschung und Praxis $2 / 95$. Ik refereer hier bewust aan Duitstalige literatuur ten einde stelling te nemen tegen de heersende gedachte in Nederland dat de Duitstalige literatuur op het gebied van externe berichtgeving ons niets te bieden zou hebben.

14. Verder is er nog wat principieel geharrewar over de vraag voor welke waarde de posities gewaardeerd moeten worden: de historische prijs of actuele waarde ('mark-tomarket'). Op hetzelfde niveau ligt de discussie of de winst op de ene en het verlies op de andere positie gesaldeerd of afzonderlijk getoond moet worden. Er is op dit gebied behoefte aan een bevoegde instantie (de wetgever of een door de wetgever gedelegeerde instantie) die deze knopen bindend doorhakt.

15. In wezen is dit geen goede maatstaf. Bij solvabiliteit gaat het om de relatie tussen het vreemd vermogen en de activa. Beiangrijk is daarbij of aan bepaalde verschaffers van vreemd vermogen voorrechten op alle (bijvoorbeeld de fiscus) of op bepaalde activa (bijvoorbeeld een hypotheek) zijn toegekend en welke risico's er zijn dat bepaalde activa niet voor de in de balans opgenomen bedragen kun- 
nen worden gerealiseerd.

16. Een dergelijke opneming kan desastreus zijn voor de ratio. Bij de grote Amerikaanse Banken kan de balanstelling in het ergste geval 19 keer zo hoog worden (G. Eilenberger in Überblick über produktbezogene Finanzinnovationen unter Gesichtspunkten der Rechnungslegung, Betriebswirtschaftliche Forschung und Praxis 2/95). In $\mathrm{Ne}$ derland is de invloed weliswaar minder groot maar toch erg belangrijk: Totaal derivaten in procenten van het balanstotaal: ABNAmro 244\%; RABO 214\% en ING 106\%. (NRC Handelsblad van 3 mei 1995).

\section{Zie bijvoorbeeld G.J. Millman: The vandals' crown.}

How rebel currency traders overthrew the world's central banks. The Free Press 1995. Zie ook de boekbespreking hiervan in NRC Handelsblad van 8 april 1995.

Ook de speculatieve effectentransacties zijn al oud. Zie bij voorbeeld Supplement B op Handelsrekenen door A.A.D. Bouwhof en J.C. Lagerwerff (Noordhof-Groningen-Batavia, 1949) waarvan ik ooit het hoofdstuk V Speculatieve effectentransacties (107 pagina's) moest bestuderen.

18. Bedoeld is de zogenaamde BIS-ratio: Richtlijn van de Raad van 18 december 1989 betreffende een solvabiliteitsratio voor kredietinstellingen $(89 / 647 / E E G)$.

\section{FASB Statement No 105 d.d. March 1990: Disclosure of information about financial instruments with off-balance sheet risk and financial instruments with concentration of credit risk.}


FASB Statement No 107 d.d December 1991 Disclosure about fair value of financial instrumenets IASC Exposure Draft 48. Financial instruments, January 1994

20. L.J Korsten en J L Hoekstra Vierkante cirkels, Volkswagen 1987, Barings Securities 1995, Leerzame voorvallen, Van Den Boom Groep, Maart 1995

\section{Collega $\mathrm{C} \mathrm{J}$. Oort is van mening dat de oplossing ligt} in een verscherping van het toezicht op de toezichthouder (Reliëf van 7 maart 1995: De Maastrichtse bril. Het Barings bankroet: incident, teken aan de wand of Engelse ziekte?)

22. Deze stelling van René Kemp, Maastricht vond ik in het dagelijkse 'bloempje' van De Limburger.

23. Wanneer er wel een maatschappelijk probleem ontstaat ligt dit anders. De zeer gedetailleerde verslaggevingsregels in de USA vinden bij voorbeeld hun oorsprong in de catastrofe rond 1930 die althans voor een deel werd toegerekend aan onvoldoende, respectievelijk onjuiste externe berichtgeving.

24. In Groot Brittannie is dit het Cadbury report (December 1992). Dit is vooral gericht op de kwaliteit van en de taakverdeling binnen het management. In de USA gaat het om het COSO report van de Treadway Commission (1992). Dit is vooral gericht op de aard en de werking van het interne beheerssysteem (internal control). 
Voor de wijze waarop de aanbevelingen van het Cadbury report thans in de praktijk worden uitgevoerd zie D A Pinn Corporate Governance disclosure in Financial Reporting 1992-93: A Survey of UK Reporting Practice, The Institute of Chartered Accountants in England and Wales 1993 In de laatste zin van dit artikel wordt duidelijk de relatie met ons onderwerp gelegd: 'The real test will be whether these changes help reduce, although they will never eliminate, the number of unanticipated company faillures and frauds.'

25 Zie in dit verband ook P. Carty. Barings' silver lining. the bonanza's and the burdens. Accountancy May 1995

26. Zie H.L. Brink: De bewoordingen van de accountantsverklaringen in Jaar in - jaar uit 7, Wolters-Noordhoff bv Groningen, 1993

27. Zie ook C.F. de Ru: Aansprakelijkheid voor de accountantsverklaring, Stichting Moret Fonds 1995

28. In het NIVRA Studierapport Treasury, financiele instrumenten en accountantscontrole bijvoorbeeld wordt geen onderscheid gemaakt tussen de door mij onderscheiden twee toepassingen.

29. Anders komt men ook in strijd met artikel 384 , lid 2 Boek 2 BW 